УДК 159.99

\title{
ФРЕЙМЫ ДОЛЖЕНСТВОВАНИЯ В СОЦИАЛЬНЫХ И ИНТИМНЫХ ОТНОШЕНИЯХ СОВРЕМЕННЫХ СТУДЕНТОК
}

\author{
Шаповал Ирина Анатольевна \\ д. П. н., профессор \\ ФГБОУ ВО Воронежский государственный \\ педагогический университет
}

Аннотация. В статье представлены междисциплинарный теоретический анализ фреймов долженствования в сфере отношений и результаты их эмпирического исследования у современных студенток. Описаны специфика входящих в них субфреймов, особая тензионность ожиданий от общества, различия возрастных трансформаций фреймов $Я$ должна и Мне должны.

Ключевые слова: долженствование, фрейм, фреймирование, социальные отношения, интимные отношения.

\section{FRAMES OF DUTY IN SOCIAL AND INTIMATE RELATIONSHIPS OF MODERN FEMALE STUDENTS}

\author{
Shapoval Irina Anatolyevna \\ Dr. Sci. (Pedagogic), Professor \\ Voronezh state pedagogical University Russia
}

\begin{abstract}
The article presents an interdisciplinary theoretical analysis of the frames of duty in the field of relations and the results of their empirical research in modern female students. The specifics of the subframes included in them, the special tensionality of expectations from society, the differences in the age transformations of the frames I am obliged and They owe me described.
\end{abstract}

Keywords: duty, frame, framing, social relations, intimate relationships.

Социальное измерение сущего и должного отражают ценности, мотивы, целеполагания, оценки, смыслы, идеалы человека. Принимая и создавая смыслы и ценности социального долженствования, мы моделируем абстрактный эталон своего Я и настраиваем свою активность на его 
достижение, что становится источником переживаний определенных состояний сознания, в т.ч. мотивационных.

Производное от долга понятие долженствования осмысляется человеком как идея некого действия [2]. Долг как моральный императив (И. Кант) означает нравственно аргументированное принуждение к поступкам, действияобязанности, фиксированные как субъективный принцип поведения в сети добровольных обязательств социального общежития: я принимаю обязательство безусловно исполнять некую обязанность.

В психологии понятие морального долга связывалось: с системой обязанностей человека в отношении группы, рождающихся из привязанности к этой группе (Э. Дюркгейм); с моральными понятиями «вины», «совести», «священности долга» и т.п., связанными с внутренним принуждением (Ф. Ницше); с понятием социального интереса как формы жизни, потенциально врождённой способности и признака психического здоровья человека (А. Адлер); с превращением потребности в самоотречении ради другого в ведущую жизненную потребность (Э. Шпрангер); с концептом «альтруистического эгоизма»: хочешь избежать стрессов - «возлюби ближнего, как самого Себя» (Г. Селье); и т.д.

Внешняя (с позиций общества) и внутренняя (с позиций Я) атрибуции долженствования в самосознании существенно различаются: перед кем человек отвечает за свои действия. Личностное долженствование акцентирует самообладание и превосходство над желаниями и удовольствиями; телеологическое атрибутирует нравственный долг человека с позиций благополучия собственного Я; законническое - постулирует обязанности аналогично законодательному кодексу общества. В последнем случае термины «следует», «нужно», «должно» могут отождествляться в определенных контекстах с терминами «обязан», «принужден», «требуется» [2].

Как можно видеть, концепты долга и долженствования необходимо включаются в индивидуальные системы значений любого социального субъекта в формах образов, символов, коммуникативных и ритуальных действий, вербальных понятий. Через их призму мы воспринимаем мир, других людей, самих себя и конструируем собственную «пристрастную» культурноисторическую модель мира. Для исследования мотивационных состояний личности в отношении ее социальных долженствований релевантным представляется использование фрейм-анализа. Понимание фрейма как когнитивной структуры сознания человека разделяют философы, социологи, 
лингвисты, психологи, что обусловливает междисциплинарный подход к его анализу и синтез различных позиций.

Социальная эпистемология единственными реальными субъектами познания утверждает живущих в той или иной социальной среде конкретных людей. С позиций дискурс-анализа, универсальные ментальные структуры вырабатываются людьми в их коммуникациях и в условиях взаимного контроля и приспособления. В новой ситуации субъект получает фреймы как готовые структуры данных о стереотипной ситуации (М. Минский) и соотносит их с входящей информацией и с собственными ценностями, целями и субъективным смыслом, объективизируя тем самым субъективные версии реальности.

В целом, фрейм определяется и как готовое социальное правило, универсально и устойчиво определяющее ситуации-события и управляющее ими в соответствии с нашей в них вовлеченностью [6], и как метакоммуникативное сообщение-послание, дающее нам инструкции или помощь в их понимании [5]).

Диахронный анализ фрейма предлагает феноменология [4]: конструируя свою жизненную реальность, человек совмещает роль как рациональный выбор и свои актуальные и релевантные мотивационные, потребностные и эмоциональные диспозиции. В итоге выбираются те элементы запаса знаний, которые будут адекватными для совладания с ситуацией, а события-ситуации объединяются в упорядоченные индивидуализированные схемы реальности, о-значенные и о-смысленные. Тем самым фрейм соединяет индивидуальное и групповое сознание: его ядро представлено абстрактным рациональным кодом знаний, значений и смыслов; периферия - субъективными представлениями [5]. Эти вариативные оценочные, эмоциональные и поведенческие элементы фрейма отражают индивидуальный опыт конкретного субъекта и постоянно настраиваются и перенастраиваются. Общие для ядра и периферии фрейма смыслы связывают значения (социальные схемы) и индивидуальные представления.

В процессе конструирования / фреймирования реальности фрейм выступает и механизмом и начальной стадией [1]: определение границ того или иного объекта, события, ситуации с помощью социально заданных правил подчиняется личностному отношению субъекта, связывающему воедино его когниции, потребности, аффекты и т.д. 
Представленные ниже эмпирические данные фрейма долженствования получены в нашем исследовании, проведенном на базе Оренбургского государственного педагогического университета в 2020-21 гг. на выборке из 36 студенток: 21 - 1 го курса и 15 - 4-го. Согласно инструкции, в течение 15 минут испытуемые должны были как можно большее количество раз закончить предложение «Я должна», затем в течение того же времени - «Мне должныl». В результате создавались индивидуальные словники долженствования.

Анализ результатов исследования. Коллективный объем словника долженствования составил 596 субфреймов, из них на 1-м курсе - 333, на 4-м 263. Средние значения составили, соответственно 16.7 и 17.5. Содержательный анализ словников показал наличие в них восьми кластеров: учеба, работа, власть / государство, материальные / бытовые блага, самосовершенствование и детско-родительские (семейные), социальные и интимные отношения. В данной работе анализируются два последних кластера, раскрывающие долженствование в области интимных и социальных отношений.

Таблица 1 Доля субфреймов социально и интимно отношенческих долженствований в общих словниках (в \%)

\begin{tabular}{|c|c|c|c|c|}
\hline \multirow{2}{*}{ Отношения } & \multicolumn{2}{|c|}{1 курс } & \multicolumn{2}{|c|}{4 курс } \\
\hline & Я должниа & Мне долюнны & Я должнна & Мне долюнны \\
\hline Социальные & 17.9 & 16.1 & 20.9 & 43.3 \\
\hline Интимные & 5.0 & 51.6 & 12.8 & 22.4 \\
\hline$\sum$ & 22.9 & 67.7 & 33.7 & 65.7 \\
\hline
\end{tabular}

Отметим главное из приведенных в таблице 1 данных.

Во-первых, в сравнении с другими фреймы Я и Мне в области отношений являются особо тензионными в плане ожиданий от общества, а значит слабо удовлетворяемыми. В целом Мне превышает $Я$ в 2 (4-й курс) и в 3 (1-й курс) раза, что указывает на эгоцентрическую нереалистичность Мне.

Во-вторых, динамика Я и Мне различна. В социальных отношениях на 1-м курсе эти фреймы уравновешены, на 4-м оба долженствования растут, но Мне обгоняет $Я$ в полтора раза. В интимных отношениях - ровно обратная картина: дисгармония 1-го курса сглаживается - $Я$ возрастает (в полтора раза), в т. ч. за счет значительного снижения Мне. Очевидно, можно говорить о возрастных трансформациях интимных и социальных долженствований. 
Таблица 2

Соотношение Я должна и Мне должны в разных отношениях

\begin{tabular}{|c|c|c|c|c|c|}
\hline \multirow[b]{2}{*}{$\begin{array}{c}\text { Долженств } \\
\text { ования }\end{array}$} & \multirow[b]{2}{*}{$\begin{array}{c}\text { Виды } \\
\text { отношений }\end{array}$} & \multicolumn{2}{|c|}{1 курс $(\mathrm{n}=21)$} & \multicolumn{2}{|c|}{4 курс $(n=15)$} \\
\hline & & $\begin{array}{c}\text { Кол-во } \\
\text { респондентов в } \\
\%\end{array}$ & $\sum_{\text {фреймов }}$ & $\begin{array}{c}\text { Кол-во } \\
\text { респондентов в } \\
\%\end{array}$ & $\sum_{\text {фреймов }}$ \\
\hline \multirow{2}{*}{ Я } & Интимные & $38.1 \%$ & 10 & $60 \%$ & 28 \\
\hline & Социальные & $71.4 \%$ & 28 & $66.7 \%$ & 25 \\
\hline \multicolumn{3}{|c|}{$\sum$} & 38 & & 53 \\
\hline \multirow{2}{*}{ Мне } & Интимные & \multirow{3}{*}{$95.2 \%$} & & $66.7 \%$ & 32 \\
\hline & Социальные & & & $53.3 \%$ & 23 \\
\hline \multicolumn{2}{|r|}{$\sum$} & & 89 & & 55 \\
\hline
\end{tabular}

Данные таблицы 2 позволяют очертить возрастные различия фреймов долженствования в разных отношениях.

На 1-м курсе фреймов Я должна в социальных отношениях почти в 3 раза больше, чем в интимных. Выделяются 3 базовых субфрейма: что должно делать (общаться; дружить; стать успешным человеком), что - не должно (не выносить мозг; не конфликтовать) и что должно уметь (красиво выходить из любой ситуации, за себя постоять). Здесь же нередки «приземленные» фреймы: вернуть долг, сходить на день рождения или на свадьбу к подруге.

Социальные и интимные отношения у первокурсников фреймируются практически одинаково: Мне должны - уважать, принимать (16), любить (12), дарить подарки, цветы, восхищение (9), помогать, поддерживать, сочувствовать (7) и т.п.

К 4-му курсу социальные и интимные $Я$ должна и Мне должны рационализируются, конкретизируются и уравновешиваются.

В социальных отношениях Я должна: быть (опрятной, вежливой ответственной, милой и т.п.), уметь (уступать), не быть (стеснительной, зависимой), делать (помогать другим; уважать других и т.п.) и не делать (закрывать глаза на человека в беде; осуждать других). Одновременно Мне должны: уступать место в автобусе, дорогу (3); подарить поездку, айфон, яркие эмоции (9).

В интимных отношениях доминируют и вне логики сочетаются Я должна в будущем (быть хорошей женой, мамой, создать / завести / построить семью, родить детей, обеспечить будущее детям, любить близких - 15) и актуальное здесь и сейчас - Мне должны (муж, мужчины, друзья - чаще всего, дарить подарки, заботу, внимание, комплименты - 11). 
Итак, фреймы как «сценарии», «схемы», «скрипты», ситуационные и когнитивные модели и «прототипы» поведения в универсальных событияхситуациях (М. Минский, Ч. Филлмор, Т. ван Дейк и др.) «монтируют» саму социальную повседневность. Они и объясняют нормальное и патологическое поведение людей, и позволяют его предсказывать благодаря включенной в «матрицу возможных событий» расстановке ролей [6]: Я должен - Мне должны.

Проведенный нами анализ фреймов долженствования показывает их прямую связь с мотивационными состояниями, объединяющими элементы субъективного опыта, личностные свойства, значимые составляющие ситуациисобытия и опосредованное влияние социально-психологических факторов. Качественное своеобразие состояния определяет доминирование в его составе в каждый данный момент характеристик психических процессов, потребностей, мотивов, когнитивных, энергетических и других составляющих [3, с. 72].

Тенденции личностной регуляции (самоуправления, саморегуляции), рационализации и автономии в современном социуме трансформируют и ценностные предикаты и содержания долженствования. Распространение практик самоконтроля, следования своему призванию, активности, стремления к успеху приводят к отказу от личной эмоциональной работы и заботы при возрастании потребности в ней, отражаясь в «культурном похолодании» (А. Хохшильд) западной культуры. Российское индивидуальное Я в социальных и интимных отношениях так же во многом граничит уже с эгоизмом и нарциссизмом. Соответствующие мотивации долженствования на достижение личного благополучия и получение удовольствия от жизни приводят к утрате принципа интерсубъективности и доминанте фреймов Мне должны, в то время как фреймы Я должен/должна все чаще приобретают в основном абстрактный и вероятностный характер.

\section{Список литературы}

1. Зелетдинова Э. А., Руденко М. Н. и др. Фрейм - анализ реальности и проблема идентичности // Общество: философия, история, культура. - 2019. № 10. https://doi.org/10.24158/fik.2019.10.1

2. Ильясов Р. Ф. Динамика ценностей долженствования современной молодежи ... дисс. канд. фил. наук: 09.00.11 / Елабуга, 2011. - 128 с.

3. Прохоров А. О., Валиуллина М. Е. и др. Психология состояний / Под ред. А. О. Прохорова. - М.: Изд-во «Когито-Центр». - 2011. - 624 с. 
4. Шюц А. Некоторые структуры жизненного мира // Вопросы социальной теории. - 2008. - Т. II, вып. 1 (2). - С. 72-87.

5. Bateson G. A Theory of Play and Fantasy // The Game Design Reader: a Rules of Play Anthology. Cambridge, 2006. P. 67-73.

6. Goffman E. Frame Analysis. An Essay on the Organization of Experience. Boston, 1986. 600 p.

(С) И.А. Шаповал, 2022 